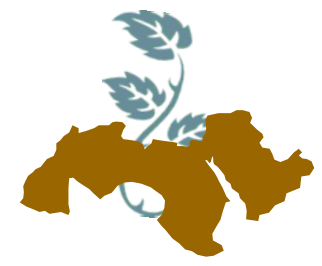

Arab Univ.

J. Agric. Sci., Ain Shams Univ., Cairo, 24(2), 655-664, 2016

\title{
ANATOMICAL AND CHEMICAL INVESTIGATIONS ON ASPARAGUS OFFICINALIS L. (ASPARAGACEAE)
}

\author{
Harb, R.K., O.S. El-Kobisy and Sally F. Desoukey \\ Agricultural Botany Dept., Fac. of Agric., Cairo Univ., Giza, Egypt
}

Keywords: Asparagus, Asparagus officinalis L. anatomy, Plant chemical analysis

\section{ABSTRACT}

Although Asparagus (Asparagus officinalis L.) is chiefly known as a vegetable herb, little information about the botanical characteristics of such plant are available. Therefore, it is aimed in this study to bring light more information about the morphological, anatomical and some important chemical contents of vegetative and reproductive organs of the plant, throughout the consecutive stages of its entire life span under the local conditions. Seeds of Asparagus (cv. Mary Washington $500 \mathrm{~W}$ ) were sown $2^{\text {nd }}$ Feb. 2013. The field experiment was carried out at the Experimental and Research Station of Fac. of Agric., Cairo Univ., Giza, Egypt during the two successive growing seasons 2013 and 2014. Asparagus is a herbaceous, perennial plant that grows up to $1.5-2 \mathrm{~m}$ height. The plant posses aerial stems (ferns) and muchbranched feathery foliage. The leaves are triangular scales like, 3-7 mm in length. The cladodes (modified stems) arise in the axis of scale leaves . Cladodes are found in fascicles (3-6) on each node. The flowers are bell- shaped, greenish white to yellowish, $4.5-6.5 \mathrm{~mm}$ long, with 6- tepals,single or in clusters of 2-3. Anatomical studies were carried out for various organs of Asparagus plant including, apex of the aerial stem, visible internode below shoot apex, median portion of the aerial stem, the cladode, median portion of spear, scale - like leaf, rhizome, adventitious root. The major chemical metabolites contents of spear were determined.

\section{INTRODUCTION}

Asparagus is a large genus with over 160 different species of herbaceous perennials crop of high economic value. The most economically important asparagus (Asparagus officinalis L.), which is a highly prized dioeciously nontraditional vegetable crop (Stajner et al 2002). Tender and unexpanded shoots, commonly called spears, are the edible organs of garden asparagus and a planting can produce spears for up to 15 years (Rubatzky and Yamaguchi, 1997). Other species used mainly as ornamental or medicinal plants. Asparagus is one of the most nutritionally well balanced vegetables in existence, which is high in folic acid, thiamin, vitamin B6 and a good source of potassium.

Modern taxonomists have placed the genus Asparagus in family Asparagaceae of Order Asparagales rather than in Liliaceae, then, the family Asparagaceae contains two other genera, Asparagopsis and Myrsiphyllum, and about 370 species, most of them are cultivated as ornamental or medicinal plants (Ali and Khan, 2009). Fellingham and Meyer (1995) determined that the family Asparagaceae is recognized by having rhizomes, branched aerial stem ,scale- like leaf, cladodes,(modified stems) and axillary flowers or axillary inflorescences.

Although Asparagus officinalis L. is chiefly known as a vegetable herb, little information about the botanical characteristics of such plant is available. Therefore, the objectives of this study was to investigate the anatomical structures of different vegetative organs during different developmental stages of plant life span. Moreover, major metabo- 
lites analysis and chlorophyll content of the plant was carried out. This would be an effort to proper delimitation of this species of the family Asparagaceae and even more. Such knowledge would be useful to specialists in various aspects of biology of such important economic plant.

\section{MATERIALS AND METHODS}

The current investigation was performed on Asparagus officinalis L. (Mary Washington 500W cultivar) of the family Asparagaceae (Asparagales). Seeds were procured from Agricultural Research Center (Institution of Vegetable), Dokii, Giza, Egypt.

The cultivation was carried out in the Agric. Experiments and Res. Station, Faculty of Agriculture, Cairo University, Giza, Egypt during the two successive growing seasons of 2013, 2014 to provide the experimental plant material.

Microscopical investigations were carried out to study the anatomical structure of Asparagus plant. Plant samples were taken at flowering time during the growing season of 2014. Specimens (3-5 mm) represented different plant organs, including:

1. The main stem represented by shoot apex, terminal and median portions.

2. The cladode (cladophyll).

3. The spear.

4. The scale-like leaf.

5. The rhizome.

6. The adventitious root.

Microtechnique procedures were carried out at the Laboratory of Agric. Bot. Dept. Faculty of Agric., Cairo University, during the second season. Plant materials were killed and fixed for at least 48 hrs. In F.A.A. (10 ml. formalin, $5 \mathrm{ml}$ glacial acetic acid, $85 \mathrm{ml}$ ethyl alcohol $70 \%$ ) and dehydrated in a normal butyl alcohol series before being embedded in paraffin wax melting point $56^{\circ} \mathrm{C}$ (Sass, 1951). Sections which were cut on a rotary microtome at a thickness of 15-20 microns were stained with crystal violet / erythrosine before mounting in Canada balsam. Slides were examined microscopically and photomicrographed.

The major chemical metabolites contents of spear were determined according to the methods of Thomas and Dutcher (1924), Arnon (1949), Blight and Dyer (1959), AOAC (2000), Anon (2009a) and Ergonul and Nergiz (2010).

\section{RESULTS AND DISCUSSION}

\section{The external feature}

Asparagus is a herbaceous, perennial and dioeciously vegetable crop, growing to $1.5-2 \mathrm{~m}$ long , with stout stems (ferns) with much-branched feathery foliage (Fig. 1.). The leaves are triangular scale- like $3-7 \mathrm{~mm}$ in length. The cladodes (modified stems) arise in the axis of scale leaves. The aerial erect shoots carry cladodes (cladophylls). The cladodes were found in fascicles (3-6) on each node (18-30mm long and about $2-3 \mathrm{~mm}$ broad).

The flowers are bell shaped, greenish -white to yellowish, 4.5-6.5mm long. Tepals are partially fused together at the base. Flowers are produced single or in clusters of 2-3 in the junctions of the branchlets. The female flower contains a welldeveloped pistil and vestigial stamens, but the male flower has six developed stamens. The fruit is small red berry at maturity, $6-8 \mathrm{~mm}$ in diameter, which is poisonous to human. The floral formula of the disc flower is as follows:

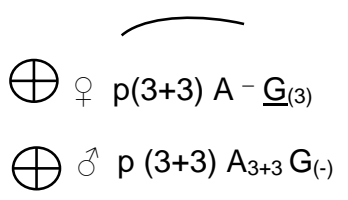

The crown consists of rhizomes, (fleshy underground stems) with adventitious roots attached to their basal portion. Furthermore the crown contains the buds of nascent spears sticking up (marketable yield). At the age of 2 years - old, the diameter of the crown was about $15-20 \mathrm{~cm}$. For best results, crowns used for planting must be 2 years -old. The young aerial stems or spears (about $20-25 \mathrm{~cm}$ long) arising from rhizomes are consumed as a vegetable.

These findings are in agreement with those of Watson \& Dallwitz (1992), Nichols, (1993), Tanming \& Chantaranathai (2011) Hyde et al (2012), Smith \& Harbott, (2012) and Harb, et al (2015).

\section{Anatomical investigations}

\section{a. The main stem}

\section{1. shoot apex}

Shoot apex meristem is usually dome shaped and arranged in two distinct zones, the outer is tunica composed of two layers of small, essentially 

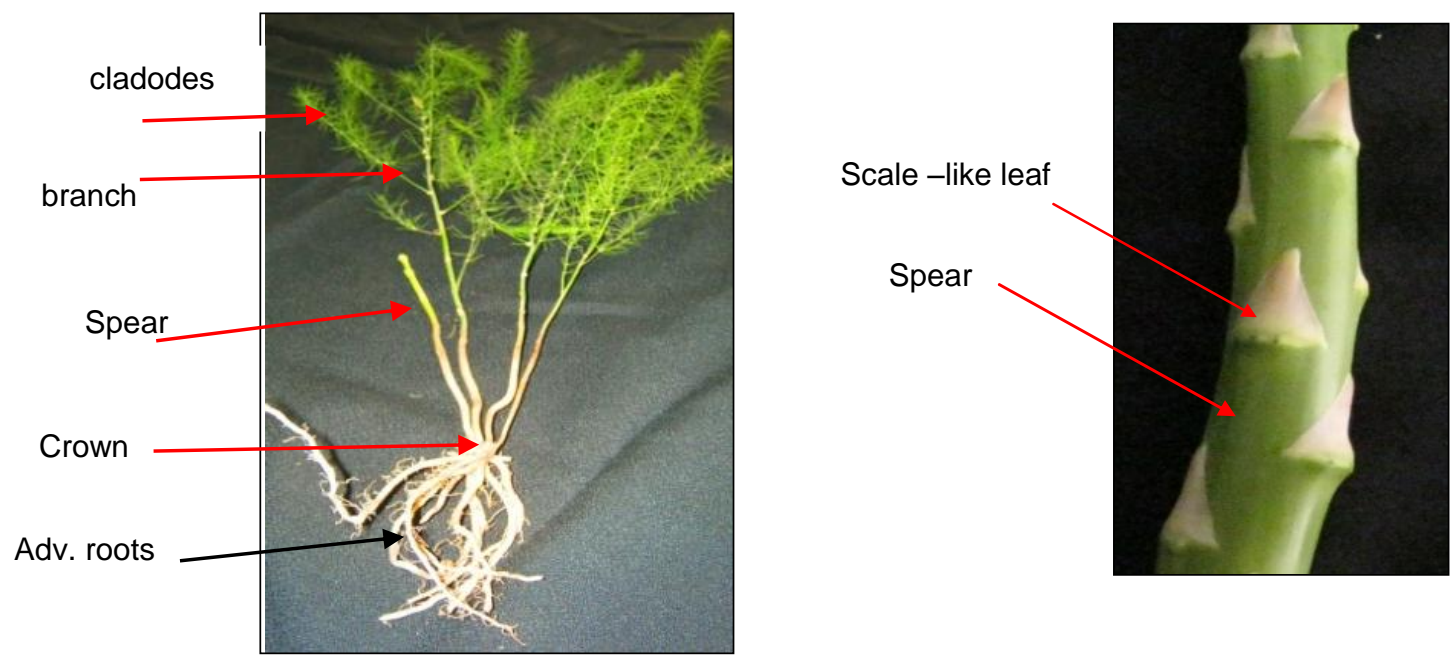

Fig.1. A Photograph of Asparagus officinalis L. showing the spear (marketable yield) and the vegetative growth of $A$. officinalis $\mathrm{L}$.

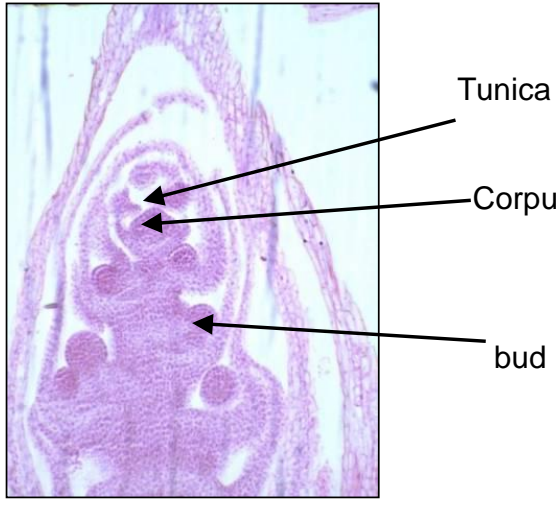

(a), $40 x$

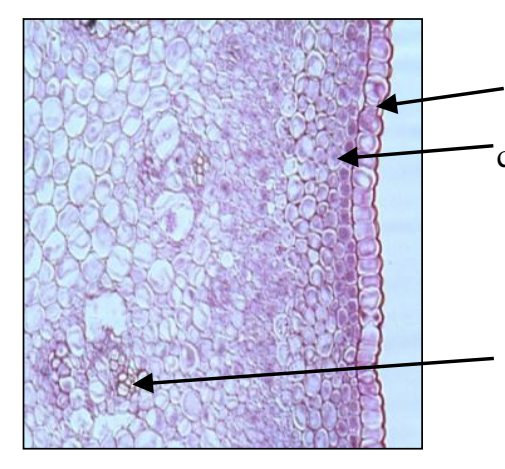

(b), $60 x$

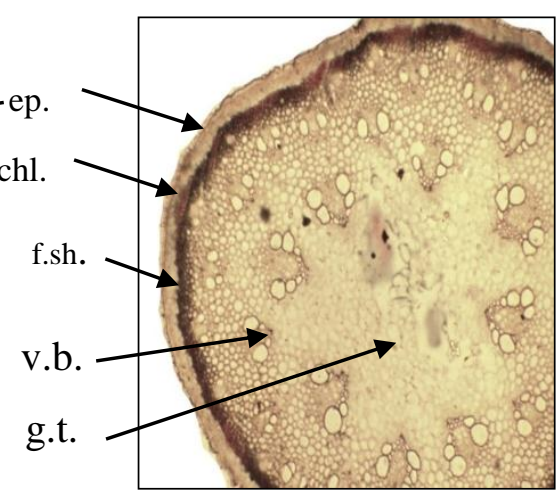

(c), $40 x$

Fig. 2. Longitudinal section through the shoot apex (a); cross sections through the terminal internode (b) and the stem (median portion) (c) of $A$. officinalis $\mathrm{L}$.

Details: ep ., epidermis; chl., chlorenchyma ; f.sh. , fiberous sheath ; v.b., vascular bundle; g.t., ground tissue .

thin - walled. The tunica is peripheral layer of cells that divided anticlinally to the surface of the meristem. The corpus is a mass of cells in the central part, the cells occur in various lines and the cells are irregular in size. The corpus cells appear to be arranged in irregular positions. Tunica responsible for initiating epidermis and other parts differentiate from corpus. Differentiate leaf primordium and stem were initiated below shoot apex as shown in Fig. $(2, a)$. It is obvious that the apex is responsible for differentiating scale - like leaf and cladodes. 


\section{Visible internode below the shoot apex}

Transverse section of visible internode below shoot apex (Fig. 2, b) show that absence of fiberous sheath below epidermis. Epidermis is followed by 2-3 layers of chlorenchyma and 4-5 layers of lacunar collenchyma. Numerous vascular bundles are embedded in the ground tissue, with pith more narrower than in median internode. Small vascular bundles are outside whereas the largest ones toward the inner side. Chlorenchyma tissue featured of idioblasts with raphides located between them. Dimensions of small vascular bundle recorded thickness of $(87.5 \mu$ and $81.2 \mu)$, whereas the corresponding dimensions of the large vascular bundle were 187.5 and $162.3 \mu$.

\section{The aerial stem (median portion)}

Transverse section of median portion of the aerial stem (Fig. 2, c) shows that the stem has an oval form with uniseriate layer of epidermis, which is interrupted with stomata and covered by a thick cuticle layer recorded thickness of $12.5 \mu$. Epidermis is followed by 2-3 layers of parenchyma tissue, then fiberous sheath in a continuous ring surrounding the stele. Fibrous sheath consists of 5-6 layers of sclerenchyma with very thick secondary walls which surrounded the vascular bundles. Through the ground tissue there are three ranks, the biggest bundles were disposed to the inside and the outside two ranks covered smaller bundles. This type of the central cylinder is known as atactostele. Dimensions of the small vascular bundle were $100 \mu$ and $112.5 \mu$ for width and length respectively, whereas the corresponding dimensions of the large vascular bundle were $162.5,200 \mu$. The central cylinder was good represented by polygonal parenchymatous cells, which increased gradually in their size towards the centre, having small triangular intercellular spaces among them. These findings are in harmony with those of Steudle (2000), Ali \& Khan (2009), Balasolu et al (2010) and Rodica (2011).

\section{b. The cladodes}

It is obvious from Fig. $(3$, a) that cladode is oval in shape. The epidermis is uniseriate oval cells and showed thickness of $25 \mu$. Cuticle layer on epidermis records thickness of $9.3 \mu$. There are two rows of prolonged radial chlorenchymatous cells and also characterized by small area of vascular tissue. The reason of increasing mesophyll tissue (thick- ness of $62.5 \mu$ ) is to compensate the lack of normal leaf. The vascular bundle is surrounded by 1-2 rows of compact parenchymatous cells. Vascular bundle is featured by two alternative arms of xylem (5-7 vessels for each arm) with two strands of phloem are expressed. The previous description synchronized with Quentin, (2009) and Raycheva \& Stojanov, (2013).

\section{c. Median portion of spear}

Transverse section of median portion of spear (Fig. 3, b) shows that oval epidermis cells recorded thickness of $12.5 \mu$ which covered with cuticle, follows by 2-3 layers of chlorenchymtous cells that recorded thickness of $37.5 \mu$. Several layers of parenchyma cells were found and followed by condense of parenchyma cells make ring around vascular bundles, then vascular bundle diffused through the ground tissues. Small external vascular bundles observed in the outermost layer but internal area showed large vascular bundles toward the central portion. Dimensions of small vascular bundle (outside) were $87.5 \mu$ and $100 \mu$ for width and length, respectively whereas the corresponding dimensions of large vascular bundle were (inside) 187.5 and $237.5 \mu$. It is obvious that, vascular bundles were diffuse in all sector without central hollow as in median portion of the aerial stem.

\section{d. The scale- like leaf}

Transverse section of scale- like leaf (Fig . 3, c) reveals that cuticle layer is exist on lower and upper epidermis and recorded average thickness of $12.5 \mu$ and $15.6 \mu$ for lower and upper epiderm respectively. Epidermis cells are long and the stomata are interspersed through the epidermis cells. Number of stomata in the abaxial side (lower side) is more than the adaxial one (upper side). Mesophyll (268.7 $\mu$ in thickness) consists of irregular parenchyma and famous of rhaphid crystals. There are poor developed vascular bundles found in continuous line. Type of vascular bundle is collateral, xylem is found in the adaxial side whereas phloem is found in the abaxial one. These results are similar with that of Rodica (2011).

\section{e. Subterranean stem (the rhizome).}

As shown in Fig. (4, a) transverse sections of rhizome (subterranean stem) are characterized by presence of amphivasal vascular bundle (central 
(Asparagaceae)

phloem vascular bundle surround by xylem) embedded in parenchyma cells with thin cell wall. Epidermis layer is replacing by storied cork (multiple cortex), which partially sobereous. Dimensions of the amphivasal vascular bundle recorded average of 281.3 and $287.5 \mu$ for width and length, respectively.

\section{f. The adventitious root}

In cross section, the adventitious root has a round form (Fig. 4,b) and appears to be formed of a series of concentric cylinder. The first layer (15.6 $\mu$ in thickness), called rhizoderma, was represented by small cells, some of them became absorbing hairs by elongation.

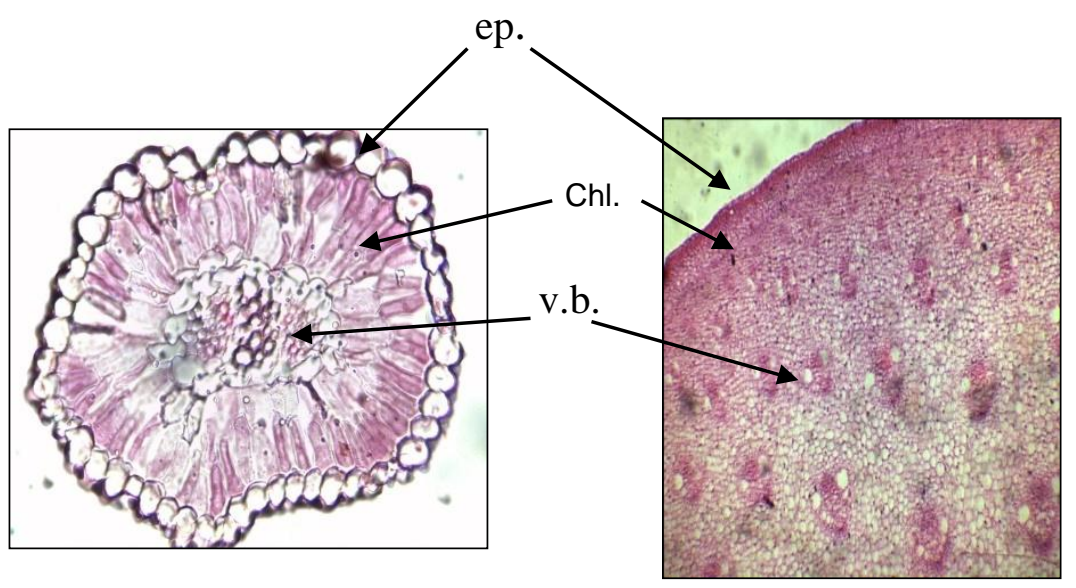

(a) , 40x

(b) , 40x

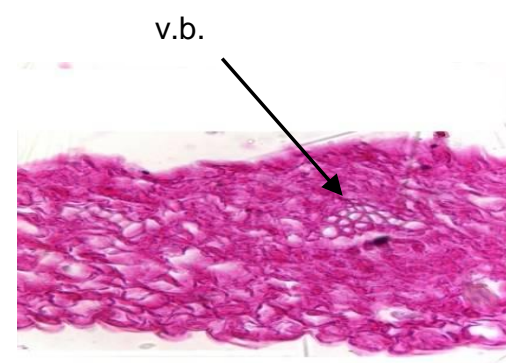

(c) , 60x

Fig. 3. Cross sections through the cladode (a), median portion of the spear (b) and through the scale -like leaf (c) of $A$. officinalis $\mathrm{L}$.

Details: ep., epidermis; chl., chlorenchyma; v.b., vascular bundle.
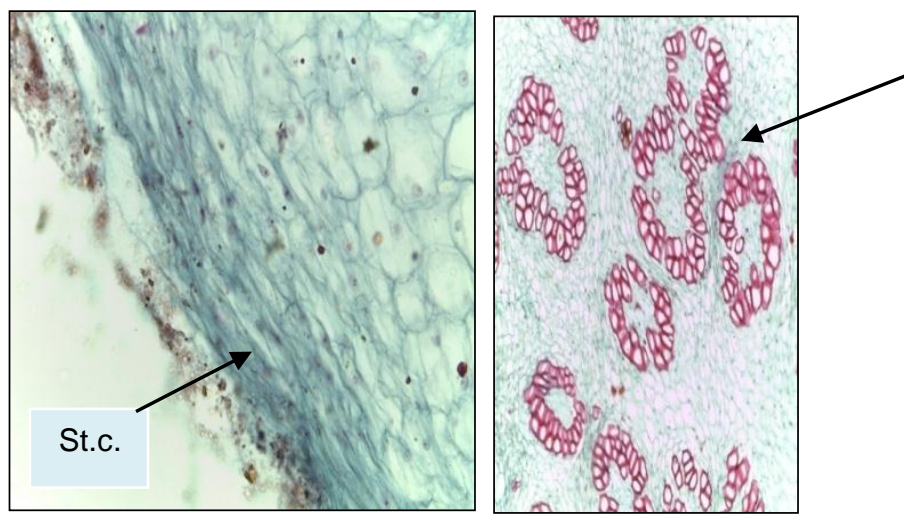

(a), $100 x$ v.b. ep.

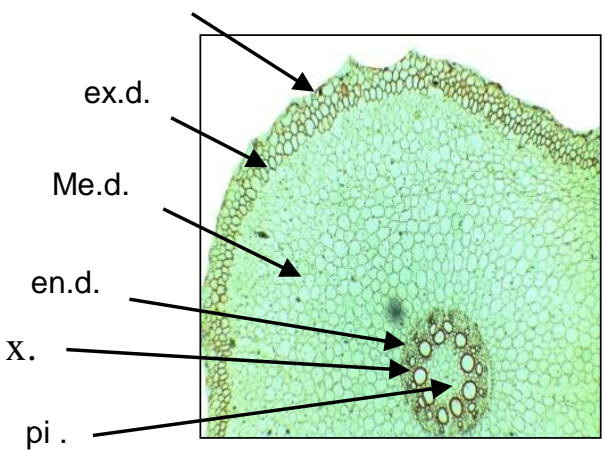

(b) , $40 x$

Fig. 4. Cross sections through the rhizome (a) and the adventitious root (b) of $A$. officinalis $L$.

Details: ep., epidermis; ex.d., exodermis; me.d., mesodermis; en.d., endodermis; x., xylem; pi., pith; St.c., storied cork. 
Exodermis consists of 4-5 layers of suberificated cells $(143.7 \mu$ in thickness). The cortical parenchyma had 15-18 ranks of oval cells, with intercellular spaces and these cells deposited the reticence substances. The storage adventitious roots of Asparagus being metamorphosed, more exactly tuberified.

The last layer of cortex, the endodermis, was formed from cells with lateral suberous walls thickening (Casper's strips) interrupted by passage cells.

The central cylinder includes the pericycle, the ligneous fascicles, the liberian fascicles, medullar rays and the medullar parenchyma (pith). Xylem was easy to distinguish through the lignified walls (9-12 bundles). The external vessels besides the pericycle, had a small diameter forming the protoxylem. The subsequent differentiated vessels to the root center, had a bigger diameter and integrates the metaxylem.

The Liberian fascicles are smaller, with cellulose walls form the protophloem and are adjacent to the pericycle. The fascicle that with a bigger diameter are disposed inside, shaping the metaphloem. The center of root is proved to be a parenchyma formed from round and oval cells (pith). Pith records $362 \mu$ in diameter.

These results are in general harmony with that given by Eschofield (1997) and Hurgoiu and Sipos (2005).

\section{Chemical determination}

\section{a. The major metabolites contents}

Samples of Asparagus officinalis L. spear were collected twice at the onset of flowering time for chemical analysis.

Percentages of the total carbohydrates, crude protein, fat, crude fiber and ash of asparagus spears are revealed in Table (1). Results illustrate that the percentages of total carbohydrate, crude protein, fat, crude fiber and ash were $44.01,10.4,4.72,22.90$ and $10.87 \%$, respectively. The fat showed the lowest content, being $4.72 \%$. On the other side, the total carbohydrate of asparagus spear recorded the highest value (44.01\%).

Similar findings were found on Asparagus officinalis plant by Cake and Bartlet (1922), Waldron and Selvendran (2006) and Aberoumand, (2010).
Table 1. Percentage of total carbohydrate, crude protein, fat, crude fiber and ash of Asparagus officinalis $L$. spear at the onset of flowering time, mean of 2 samples.

\begin{tabular}{|l|c|}
\hline Composition of spear & Percentages (\%) \\
\hline Total Carbohydrate & 44.01 \\
Crude Protein & 10.40 \\
Fat & 04.72 \\
Crude fiber & 22.90 \\
Ash & 10.87 \\
Humidity & 07.10 \\
\hline
\end{tabular}

\section{b. Total chlorophylls, sugars and thiamin}

Table (2) reveals the average of total chlorophyll ( $a$ and $b$ ), total sugars (reducing and nonreducing) as well as thiamin (Vit . $\left.B_{1}\right)$ of asparagus spears (d.wt.).

Data show that the content of total chlorophyll was $20.01 \mu \mathrm{g} / \mathrm{g}$. The chlorophyll (a) and (b) contents were $12.93,6.57 \mu \mathrm{g} / \mathrm{g}$, respectively. Also, data show that the content of total sugar was 2.28 $\mathrm{mg} / \mathrm{g}$. The contents of reducing and non- reducing sugar were $0.46,1.31 \mathrm{mg} / \mathrm{g}$, respectively. With respect to vitamin $B_{1}$ (thiamin) data show that the content of thiamin was $0.003 \mu \mathrm{g} / \mathrm{g}$ d.wt.

These results are in harmony with those of Deputy (1993), Hassan, Neveen (2001) and Sakaguchi et al (2008).

Table 2. Chlorophylls, sugars and thiamin (Vit. $\left.B_{1}\right)$ contents of Asparagus officinalis L. spear at the onset of flowering time, means of 2 samples

\begin{tabular}{|c|c|}
\hline Biochemicals & Measurements \\
\hline Chlorophyll(a) & $12.93 \mu \mathrm{g} / \mathrm{g} \mathrm{d} . \mathrm{wt}$. \\
Chlorophyll(b) & $06.57 \mu \mathrm{g} / \mathrm{g}$ \\
Total chlorophylls & $20.01 \mu \mathrm{g} / \mathrm{g}$ \\
Reducing sugars & $00.46 \mathrm{mg} / \mathrm{g}$ \\
Non reducing sugars & $01.31 \mathrm{mg} / \mathrm{g}$ \\
Total sugars & $02.28 \mathrm{mg} / \mathrm{g}$ \\
Thiamin (Vit. $\left.\mathrm{B}_{1}\right)$ & $00.003 \mu \mathrm{g} / \mathrm{g}$ \\
\hline
\end{tabular}




\section{c. The organic acid contents}

Results of the organic acid contents of Asparagus officinalis $\mathrm{L}$. at the onset of flowering time of the corresponding chromatogram peaks are given in Table (3) and Fig. (5).

HPLC analysis of spear at the onset of flowering time was known to be a complex mixture contains 6 components of organic acids. The components were designated according to their retention times for further reference. Many could be identified according to the detector response.

Results illustrate that the contents of oxalic, citric, tartaric, lactic, formic and acetic acid were 27.58, 0.22, 3.19, 90.37, 26.72 and $8.03 \mathrm{mg} / 100 \mathrm{~g}$, respectively. Similar findings were recorded on Asparagus officinalis L. plant by Stephen and Mitchell, (2013) and, also Yeasmin et al (2013) who found that organic acids have important role in the allelopathic responses of asparagus replanting problem.
Table 3. HPLC analysis of organic acids in asparagus spear at onset of flowering time

\begin{tabular}{|c|c|l|}
\hline $\mathbf{R T}(\mathbf{m i n})$ & $\begin{array}{c}\text { Contents } \\
\text { (mg/100g d.wt.) }\end{array}$ & Org.acid \\
\hline 6.68 & 27.58 & Oxalic acid \\
8.15 & 0.22 & Citric acid \\
8.90 & 3.19 & Tartaric acid \\
12.85 & 90.37 & Lactic acid \\
13.47 & 26.72 & Formic acid \\
14.52 & 8.03 & Acetic acid \\
\hline
\end{tabular}

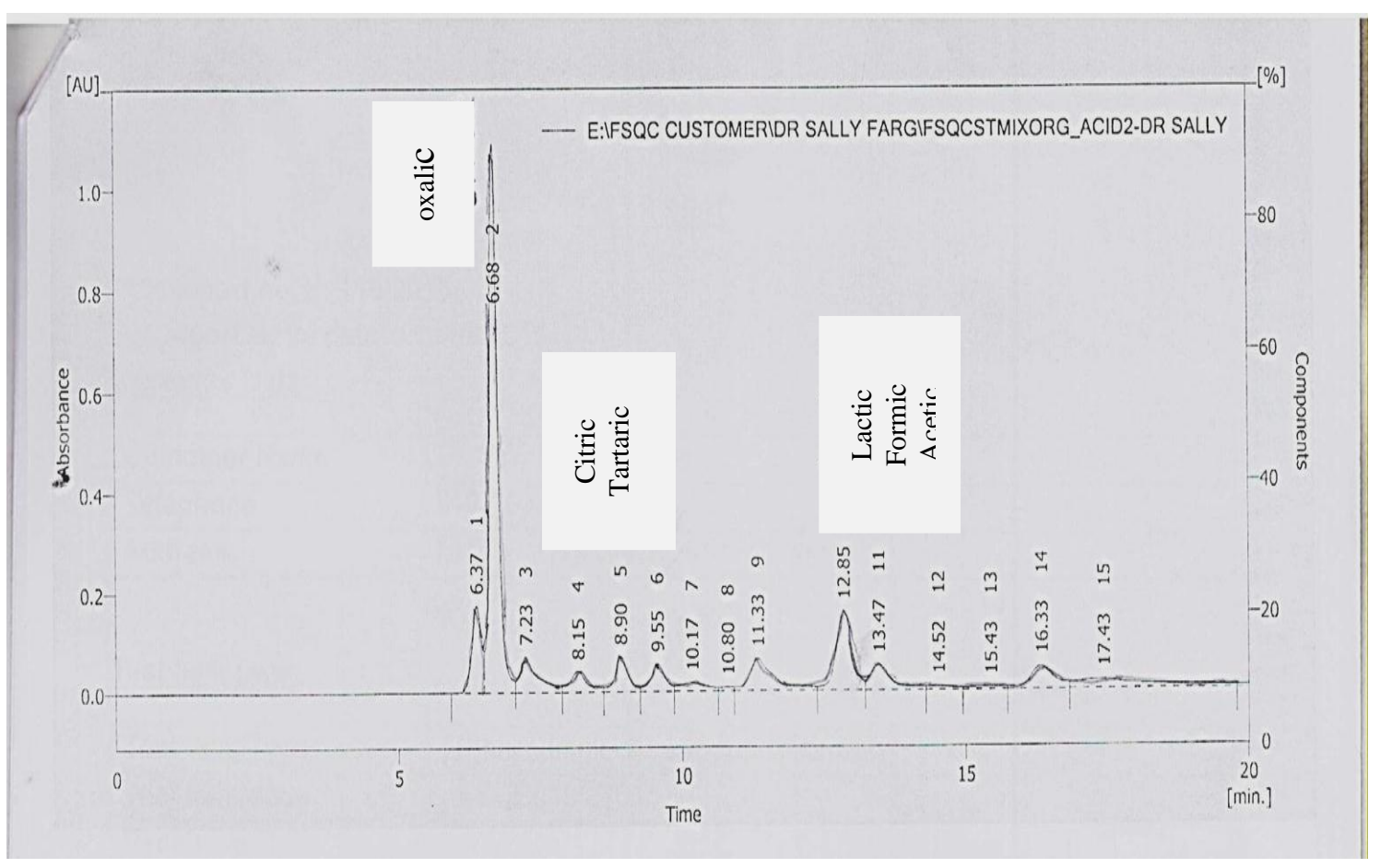

Fig. 5. High performance liquid chromatogram of organic acids of Asparagus officinalis L. spear 


\section{REFERENCES}

Aberoumand, A. 2010. Comparsion of chemical analsis of Asparagus officinalis and Chlorophytum comocum; Iranian Plant Foods Indian, J. Agri Res., 44(1), 56-61.

Ali, S.I. and Khan, S.W. 2009. Asparagaceae. In: Flora of Pakistan (Eds) Ali, S. and M. Qaiser, inst. Plant conser., Univ. Karachi, Karachi and Missouri Bot. Press, Missour Bot. Garden, St. louis, Missouri, USA, 217, 1-24.

Anon 2009a. APG (The Angiosperm Phylogeny Group).An update of the Angiosperm group classification for the order and families of flowering plants: APG 111. Botanical Journal of the Linnean Society.

A.O.A.C 2000. Official Method of Analysis, Kjeldahl method NO.984.13, 18 th edition, Association of official Analytical Chemists. Washington DC. Arlington, Virgina, USA. chapter 4, $31 \mathrm{p}$.

Arnon, D.L. 1949. A copper enzyme is isolated chloroplast poly phenol oxidase in Bvulgaris Plant Physiol. 24, 1-15.

Balasolu, L.B., Ejenaru, C., Bejenaru. L.E., Mogoanu, G.D. and Popescu, I.T. 2010. Histo-anatomical Data concerning the vegetative organs of Scilla biofolial (Liliaceae). Current Health Science Journal. 36(2), 98-100.

Blight, E.G. and Dyer, W.J. 1959. A rapid Method of total lipid extraction and purification .Canadian Journal of Biochemistry and Physiology, 37(8), 911-917.

Cake, W.E. and Bartlet, H.H. 1922. The carbohydrate content of the seed of Asparagus officinalis L. J. Bio. Chem. 51, 93-102.

Deputy, J. 1993. Asparagus / home Garden vegetable .Published by Agriculture and Human Resources (CTAHR) and issued in furtherance of cooperative extension work. pp. 1-4.

Ergonul, P.G. and Nergiz, C. 2010. Determination of organic acids in olive fruit by HPLC. Food Sci ., 28, 202-205.

Eschofield, P. 1997. The Involvement of Fusarium, Auto toxins and Herbicide Residucs in the Asparagus (Asparagus officinalis L.) Replant Problem. Ph.D thesis in Plant Science. At Massey University. 182p.

Fellingham, A.C. and Meyer, N.L. 1995. New combination and a complete list of Asparagus species In Southern Africa (Asparagaceae). Bothalia 25, 205-209.

Harb, R.K., El-Kobisy, O.S. and Desouky, S.F. 2015. Botanical investigations on Asparagus officinalis L plant (Asparagaceae). Bull. Fac. Agric., Cairo Univ., 66(1), 68-75.

Hassan, Neveen. A. 2001. Growth, Yield, Spear Quality and Some Genetical and Character of six Asparagus officinalis L. Cultivars. Department of Vegetable Crops Faculty of Agriculture. Cairo University. 137p.

Hurgoiu, F. and Sipos, M. 2005. A comparative study of the root and stem anatomy of Asparagus (Asparagus officinalis.) Exvitro plantlets and vitro plantlets. PHD student. University from Oradea. Analele Univ. Oradea. Fasc. Biologie, Tom. pp. 181-184.

Hyde, M.A., Wursten, B.T. and Balling, P. 2012. Asparagaceae flora of Zimbabwe Royal Botanical Gardens 13(1), 385.

Nichols, M.A. 1993. Asparagus officinalis L. in: siemonsma, d.s \& kasem piluek (Editors). Plant Resources of south - East Asia NO. 8. Vegetables. Pudoc Scientific Publisher. Wgeningen, Netherlands. pp. 91-93.

Quentin, C.B. 2009. "The molecular organography of plants "Oxford, Univ. Press Published in United States by Oxford University Press Inc., New York. USA, 288 p.

Raycheva, T.K. and Stajanov, K. 2013. Comparative anatomical study of five species of genus Asparagus 112 Bulgaria. Trakia Diurnal of Sciences. 11(2), 104-109.

Rodica, B. 2011. Some aspect of Asparagus BRA chyphyllustucz . (Asparagaceae). Anatomy. Faculty of Nature and Agriculture Science, Ovidius University, Constantza. pp. 7-11.

Rubatzky, V.E. and Yamaguchi, M. 1997. World vegetables principles production and Nutritive values. International Thomson publishing $2^{\text {nd }}$ Edition., New York, USA, 843 p.

Sakaguchi, Y., Ozaki, M., Yamaguchi, M., Fuku, Y., liwasa, K., Motoki, S., Suzuki, T. and Okubo, H. 2008. Mador anthocyanins from purple asparagus (Asparagus officinalis). Phytochemistry. 69(8), 1763-1766.

Sass, J.S. 1951. Botanical Microtechnique. Professor of Botany lowa state collage. Second Edition. The lowa State Collece. Press building, Ames, lowa. 228 p.

Smith, R. and Harbott, E. 2012. World check list of selected families. facilitated By the royal botanical Garden, kew. Publishing on the internet at: http://apps.kew.org/wcsp/. (accessed 26 october 2012).

Stajner, N., Bohane, C.B and Javornik, B. 2002. Genetic Variability of economically important Asparagus species as revealed by genome 
size analysis and rDNA its polymorphism. Plant Science. 162, 931 -937.

Stephen, C. and Mitchell, S.C. 2013. Asparagus, urinary odor and 1-2- dithiolane -4-carboxylic acid. Perspectives in Biology and Medicine. Abst., 56, 314-315.

Steudle, E. 2000. Water uptake by roots : effects of water deficit . J. Exp. Bot., 51, 1531-1542.

Tanming, W. and Chantaranathai, P. 2011. Account of Asparagaceae in Thailand. Applied taxonomic Research center, tropical nature HIStory 12(1), 43-53.

Thomas, W. and Dutcher, R.A. 1924. The colormetric determination of carbohydrates in plant by picric acid reduction method \% the estimation of reducing sugars and sucrose. Journal of American Chemical Society 46, 1662.
Waldron, K. and Selvendran, R. 2006. Compostion of the cell wall of different Asparagus (Asparagus officinalis). tissues. Article first published on line. Physiologia Plantarum. 80, 568-575.

Watson, L. and Dallwitz, M.J. 1992. The families of flowering plants: decriptions, Illustration, identification, and information. Delta Newsletter 8, 7-9.

Yeasmin, R., Motok, S. and Yamamoto, S. 2013. Allelochemicals inhibit the growth of subsequently replanted asparagus (Asparagus officinalis L.). Agriculture and Horticulture: an International Journal for Sustainable Production System. 29, 165-175. 